\title{
Influence of Compost Recycling and Magnesium Supplement on Physical and Chemical Traits of Animal Manure Compost
}

\author{
Jin-Eui Lee ${ }^{1}$, Jung-Hoon $\mathrm{Kwag}^{2}$ and ChangSix $\mathrm{Ra}^{1} *$ \\ ${ }^{1}$ Department of Animal Life System, College of Animal Life Sciences, Kangwon National University, Chunchon 200-701, \\ South Korea, ${ }^{2}$ National Institute of Animal Science, RDA, Suwon, 441-350, South Korea
}

\begin{abstract}
A series of experiments were performed to study the influence of the following parameters on the physical traits and composition of swine manure compost: (1) addition of magnesium $(\mathrm{Mg})$ at a molar ratio of 1.2 with respect to $\mathrm{PO}_{4}$, and $(2)$ reutilization of compost containing $\mathrm{MgNH}_{4} \mathrm{PO}_{4} \cdot 6 \mathrm{H}_{2} \mathrm{O}$ (magnesium ammonium phosphate, MAP). Three independent batch tests were conducted for replication: batch test I-control $(\mathrm{C})$ and $\mathrm{Mg}$ added $(\mathrm{T})$, batch test II-C, $\mathrm{T}$ and compost recycle ( $\left.\mathrm{T}_{\mathrm{R} 1}\right)$, and batch test III-C, $\mathrm{T}$ and compost recycle $\left(\mathrm{T}_{\mathrm{R} 2}\right)$. Magnesium addition and compost reutilization had no adverse effect on the degradation of organic matter. Reuse of the compost, however, had a clear effect on the total nitrogen (TN) and total phosphorus (TP) contents in the final compost. Repeated compost reutilization as a bulking material was resulted in composts rich in $\mathrm{N}$ and $\mathrm{P}$. Upon adding the $\mathrm{Mg}$ supplement to the composting materials, the ortho-phosphate (OP) to $\mathrm{TP}$ ratio decreased due to the MAP crystallization reaction. The decrease in the OP/TP ratio and the increase in the TP content of the compost indicate that water-soluble phosphate is converted into a slow-release phosphate by the formation of crystals during composting. X-ray diffraction analysis of the irregular shaped crystals in the compost indicated that they are MAP crystals and that the crystallization of MAP begins immediately after the addition of the Mg supplement. The Mg addition to composting materials and the reutilization of compost as a bulking material would be a practical means to conserve nutrient content.
\end{abstract}

(Key words : Bulking materials, Magnesium ammonium phosphate, Swine manure)

\section{INTRODUCTION}

Composting is an aerobic biological process in which microorganisms decompose organic matter (OM) into a humus-like product under controlled conditions. Organic wastes, including livestock manure, are cheap sources of compost, and composting is the most efficient way to convert manure into an organic amendment, a soil conditioner. Using compost in agricultural fields is an easier way to recycle $\mathrm{OM}$ into the soil and is compatible with organic food production. Manure compost also has a beneficial effect on the soil structure because it increases soil OM, thereby enhancing plant growth [Hoitink and Fahy, 1986].

However, problems associated with nutrient content in compost must be addressed. Compared with chemical fertilizers, the nitrogen content of animal manure compost is very low. A large amount of ammonia is lost during the active thermophilic decomposition of OM[Kirchmann and
Witter, 1989 Kithome et al., 1999 Kuroda et al., 2004 Bueno et al., 2008], which results in a reduction in the nitrogen content of the final compost. A significant amount of nutrients in compost is also easily lost through surface runoff and vertical leaching when the compost is spread over soil. Moreover, because of the use of bulking material such as sawdust, high costs are incurred in achieving proper composting, which adds to the heavy financial burden on farmers. For example, most of farmers in Korea have been using sawdust as a bulking material for the composting of animal manure, and the purchasing price of sawdust is around USD 120 ton $^{-1}$, although there is a little variation. Therefore, it is desirable to develop a strategy to simultaneously increase the nutrient content of compost and reduce the use of bulking agents.

Adding $\mathrm{Mg}$ salts to composting materials is known to reduce ammonia loss during composting by inducing the formation of struvite or magnesium ammonium phosphate (MAP) crystals, thereby enhancing compost quality [Jeong

\footnotetext{
* Corresponding author: Department of Animal Life System, Kangwon National University, Chunchon 200-701, South Korea. Tel: +8233-250-8618, Fax:+82-33-251-7719, E-mail: changsix@kangwon.ac.kr
} 
and Kim., 2001 Jeong and Hwang, 2004 Lee et al., 2009]. Since swine manure contains less $\mathrm{Mg}$ relative to $\mathrm{NH}_{4}$ and $\mathrm{PO}_{4}{ }^{3-}$, the addition of $\mathrm{Mg}$ enhances MAP crystallization during swine manure composting. MAP is the crystallized form of $\mathrm{MgNH}_{4} \mathrm{PO}_{4} \cdot 6 \mathrm{H}_{2} \mathrm{O}$ and is used as a slow-release fertilizer [Munch and Barr, 2001]. The MAP crystallization reaction has a beneficial effect on the conservation of nitrogen and phosphorus in compost, making MAP an appropriate fertilizer for container plants, turfs, tree seedlings, ornamentals, vegetables, and flower boards [Bridger et al., 1962]. Furthermore, MAP is a very valuable slow- release fertilizer that is effective in acidic and hilly terrain it is not easily flushed away by rainfall, so it is also appropriate for use in flood-prone areas [Lee et al., 2009]. Inducing MAP crystal formation during animal manure composting improves compost quality by conserving nutrients and releasing them very slowly in the soil. Furthermore, because the degradability of common bulking agents such as sawdust is very low, reusing the final compost as a bulking material proves an economical way to produce high-quality composts. In this study, a series of composting experiments was performed to observe how the compositions of compost are affected by the addition of $\mathrm{Mg}$ and by recycling of compost containing MAP crystals.

\section{MATERIALS AND METHODS}

Three sequential batch tests were conducted in series to identify the effect on final compost of adding $\mathrm{Mg}$ and of recycling compost containing MAP crystals: batch test Icontrol (C) and $\mathrm{Mg}$ added (T), batch test $\mathrm{II}-\mathrm{C}, \mathrm{T}$ and compost recycle $\left(\mathrm{T}_{\mathrm{R} 1}\right)$, and batch test III-C, $\mathrm{T}$ and compost recycle $\left(\mathrm{T}_{\mathrm{R} 2}\right)$. Each batch test was independent, and the traits of Mg-treated and recycled compost was compared with control compost in each test. $\mathrm{MgCl}_{2}$ was used as the $\mathrm{Mg}$ source and added to $\mathrm{T}, \mathrm{T}_{\mathrm{R} 1}$, and $\mathrm{T}_{\mathrm{R} 2}$ at a molar ratio of 1.2 with respect to the $\mathrm{PO}_{4}$ content in swine manure. Half of the bulking materials for $\mathrm{T}_{\mathrm{R} 1}$ and $\mathrm{T}_{\mathrm{R} 2}$ in batch tests II and III were replaced by $\mathrm{T}$ and $\mathrm{T}_{\mathrm{R} 1}$ compost obtained from the preceding batch tests (tests I and II, respectively). The experimental recipe is given in Table 1 . In all batch tests, 3 $\mathrm{kg}$ of swine manure was mixed with sawdust, compost, or both, such that the moisture after mixing was $65 \%$. Composting was carried out in 8-L reactors that were airtight except for a continuous air supply at the bottom, which maintained the aerobic condition. The reactors were made by plexiglas and insulated with expanded 10 -cm-thick polystyrene. For each test, the continuous air flow was driven by an aerator at $0.25 \mathrm{~L} \mathrm{~min}^{-1}$. A temperature probe was inserted into the reactor to monitor the temperature via a data logger connected to a computer. The composting materials were mixed manually every $3 \mathrm{~d}$ for uniformity, and composting was stopped after achieving a uniform room temperature under all treatment conditions. During the experimental period, room temperature was in the range of $15-23^{\circ} \mathrm{C}$ and the composting materials remained in those conditions for approximately $27 \mathrm{~d}(25-30 \mathrm{~d})$ was taken for reactor temperature to reach room temperature). Upon completionof composting, the materials were manually mixed and samples for final composts were collected.

For each test, initial and final compost samples were collected and analyzed. Samples were analyzed to determine the $\mathrm{OM}$ content, $\mathrm{pH}$, total nitrogen (TN) content, ammonium $\left(\mathrm{NH}_{4}\right)$ content, orthophosphate (OP) content, and total phosphate (TP) content. Also, the compost samples were analyzed by $\mathrm{X}$-ray diffractometer (PANalytical, X'pert-pro) to determine the formation of crystals during composting. The temperature was monitored automatically using the data logger, and $\mathrm{pH}$ was determined after $2 \mathrm{~h}$ of shaking in a 50- fold dilution of the samples in distilled water. The $\mathrm{OM}$ content was determined by burning the samples at $550^{\circ} \mathrm{C}$ for $4 \mathrm{~h}$. The $\mathrm{NH}_{4}$ and $\mathrm{OP}$ contents were analyzed using an auto analyzer

Table 1. Layout of the experiment

\begin{tabular}{|c|c|c|c|c|c|c|c|c|}
\hline \multirow{2}{*}{ Parameter } & \multicolumn{2}{|c|}{ Batch Test I } & \multicolumn{3}{|c|}{ Batch Test II } & \multicolumn{3}{|c|}{ Batch Test III } \\
\hline & $\mathrm{C}$ & $\mathrm{T}$ & $\mathrm{C}$ & $\mathrm{T}$ & $\mathrm{T}_{\mathrm{R} 1}$ & $\mathrm{C}$ & $\mathrm{T}$ & $\mathrm{T}_{\mathrm{R} 2}$ \\
\hline Manure (kg) & 3.0 & 3.0 & 3.0 & 3.0 & 3.0 & 3.0 & 3.0 & 3.0 \\
\hline Sawdust (kg) & 0.8 & 0.8 & 0.98 & 0.98 & 0.49 & 0.81 & 0.81 & 0.405 \\
\hline Compost (kg) & - & - & - & - & $0.49^{\mathrm{a}}$ & - & - & $0.405^{\mathrm{b}}$ \\
\hline Mg/OP molar ratio & - & 1.2 & - & 1.2 & 1.2 & - & 1.2 & 1.2 \\
\hline Moisture content (\%) & 60.0 & 59.1 & 60.6 & 61.4 & 60.7 & 63.7 & 63.9 & 64.2 \\
\hline
\end{tabular}

${ }^{\mathrm{a}}$ Utilization of the compost from $\mathrm{T}$ of Run $1,{ }^{\mathrm{b}}$ Utilization of the compost from $\mathrm{T}_{\mathrm{R} 1}$ of Run 2 
(Quick Chem 8000, LACHAT) after dilution in distilled water, and the TP content was analyzed after digestion with Block Digester (LACHAT, Model- BD 46). The TN content was measured using a different auto analyzer (rapid $\mathrm{N}$, Elementar $\mathrm{GmbH}$ ). All other analyses were performed in accordance with the Standard Methods [APHA, 1995].

\section{RESULTS AND DISCUSSION}

Fig. 1 show the temperature profile acquired during the composting process in batch test III. Since the temperature profiles of all three batch tests are very similar, Fig. 1 could be considered as representative data for the temperature profiles of all treatments. In spite of $\mathrm{Mg}$ addition in all batch tests $(\mathrm{T})$ and reusing compost from the previous batch test in batch tests II and III ( $\mathrm{T}_{\mathrm{R} 1}$, and $\left.\mathrm{T}_{\mathrm{R} 2}\right)$, the thermophilic condition was easily established and maintained for several days in all three batch tests. All composting reactors in batch tests I, II, and III reached temperatures of up to $70^{\circ} \mathrm{C}$, implying $\mathrm{Mg}$ addition to the composting materials and replacing half of the bulking materials with MAP-containing compost (produced by the addition of $\mathrm{Mg}$ ) did not affect the decomposition of OM. A previous study reported that although there is a slight variation in the maximum temperature, the addition of $\mathrm{Mg}$ creates an optimum environment for decomposing $\mathrm{OM}$, even if $\mathrm{Mg}$ is present at high levels [Lee et al., 2009].

Temperature acts as an indicator of the status of decomposition of $\mathrm{OM}$ and compost quality, since the $\mathrm{OM}$ decomposition and temperature increase simultaneously occur due to the action of microorganisms during the composting process (Raut et al., 2008). Initially, mesophilic organisms develop and begin to break down the readily available OM.

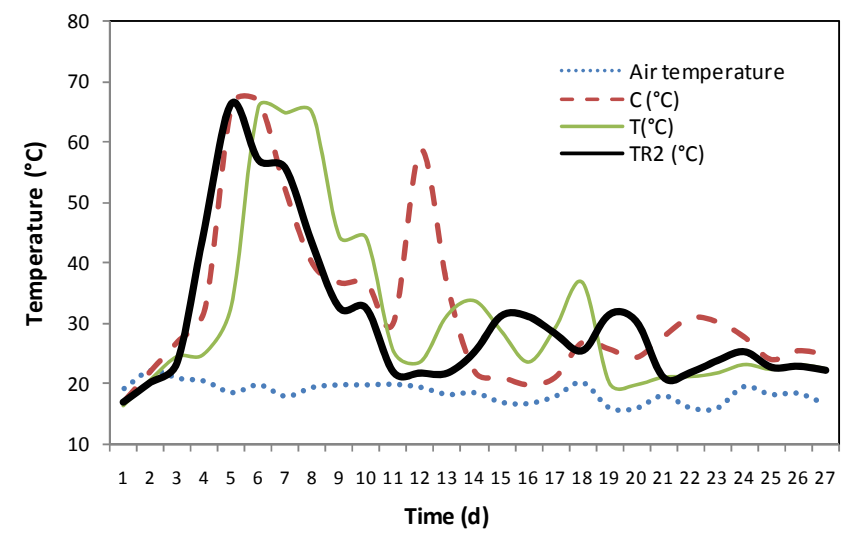

Fig. 1. Composting temperature during the batch test III.
Then, the thermophilic stage is established at $50^{\circ} \mathrm{C}$ or higher [Zhu, 2007] and most of the OM is broken down by the action of thermophilic bacteria during the active decomposition phase. Stentiford [1996] stated that a temperature of $55-65^{\circ} \mathrm{C}$ is necessary to destroy all pathogens and larvae, but mesophilic temperatures $\left(45-55^{\circ} \mathrm{C}\right)$ must be maintained for maximum biodegradation. A longer curing stage also improves compost quality by reducing particle size and bacterial accumulation [Graves et al., 2000].

Moisture content remained essentially unchanged during the experiment because the airtight condition was strictly maintained during composting to thermally insulate the reactor so that accurate observations of temperature changes could be made.

Reuse of the final compost containing MAP crystal as bulking material has a clear effect on TN content in the final compost (Table 2). The $\mathrm{N}$ content of the final compost of $T_{R 1}$ and $T_{R 2}$ is higher than others $(C$ and $T)$ in batch tests II and III, so the $\mathrm{C} / \mathrm{N}$ ratios of those final composts were lower. This fact may indicate that the Mg addition and the repeated reuse of compost containing MAP as a portion of the bulking material as in $\mathrm{T}_{\mathrm{R} 1}$ and $\mathrm{T}_{\mathrm{R} 2}$ may conserve $\mathrm{N}$, leading to a N-rich compost. It is known that a large amount of $\mathrm{N}$ is emitted as ammonia gas during the composting of $\mathrm{OM}$, resulting in the deterioration of compost quality. Kirchmann and Witter [1989] stated that $44 \%$ of the TN is lost through ammonia volatilization during poultry manure composting. Kithome et al. [1999] reported that $47-62 \%$ of the TN is lost through ammonia emission when poultry manure composting is carried out for $25 \mathrm{~d}$. This large loss of nitrogen degrades the quality of compost as fertilizer and also raises a severe odor problem that is hazardous to the environment.

As the OM decomposition occurred and mineralization progressed during the composting process, the TP content $\mathrm{kg}^{-1}$ increased. Conversely, $\mathrm{PO}_{4}$ level in the final compost decreased, and the reduction efficiencies of $\mathrm{PO}_{4}$ were much higher in Mg-added treatments $\left(\mathrm{T}, \mathrm{T}_{\mathrm{R} 1}\right.$, and $\left.\mathrm{T}_{\mathrm{R} 2}\right)$ than the controls where no $\mathrm{Mg}$ was added. This observation may be attributed to MAP crystal formation during composting. A significant amount of organic phosphate and poly-phosphate is transformed into OP during the active decomposition phase, and this new $\mathrm{PO}_{4}$, combined with the original $\mathrm{PO}_{4}$ of the manure, reacts with the abundant $\mathrm{NH}_{4}{ }^{+}$and the added $\mathrm{Mg}$ to form struvite crystals in the compost.

In addition, clear evidence of the extent of MAP 
Table 2. Changes in composting parameters

First batch test

\begin{tabular}{|c|c|c|c|c|}
\hline Parameters & Time & Control & $\mathrm{T}^{\mathrm{a}}$ & \\
\hline \multirow{2}{*}{ OM (\%) } & Before & 34.6 & 35.0 & \\
\hline & After & 30.7 & 34.1 & \\
\hline \multirow{2}{*}{ Moisture (\%) } & Before & 60.1 & 59.1 & \\
\hline & After & 62.8 & 58.3 & \\
\hline \multirow{2}{*}{$\mathrm{NH}_{4}-\mathrm{N}\left(\mathrm{mg} \mathrm{kg}^{-1}\right)$} & Before & 776 & 856 & \\
\hline & After & 607 & 639 & \\
\hline \multirow{2}{*}{ TN (\%) } & Before & 1.04 & 1.27 & \\
\hline & After & 1.1 & 1.16 & \\
\hline \multirow{2}{*}{$\mathrm{C} / \mathrm{N}$ ratio } & Before & 33.3 & 27.5 & \\
\hline & After & 27.9 & 29.4 & \\
\hline \multirow{2}{*}{$\mathrm{OP}\left(\mathrm{mg} \mathrm{kg}^{-1}\right)$} & Before & 6,966 & 6,588 & \\
\hline & After & 5,131 & 4,489 & \\
\hline \multirow{2}{*}{$\mathrm{TP}\left(\mathrm{mg} \mathrm{kg}^{-1}\right)$} & Before & 8,978 & 8,137 & \\
\hline & After & 10,928 & 10,471 & \\
\hline \multirow{2}{*}{$\mathrm{OP} / \mathrm{TP}(\%)$} & Before & 77.6 & 81.0 & \\
\hline & After & 47.0 & 42.9 & \\
\hline \multirow{2}{*}{$\mathrm{pH}$} & Before & 7.2 & 7.3 & \\
\hline & After & 8.8 & 8.0 & \\
\hline \multicolumn{5}{|l|}{ Second batch test } \\
\hline Parameters & Time & Control & $\mathrm{T}^{\mathrm{a}}$ & $\mathrm{T}_{\mathrm{R} 1}{ }^{\mathrm{D}}$ \\
\hline \multirow{2}{*}{ OM (\%) } & Before & 35.2 & 34.2 & 33.4 \\
\hline & After & 36.2 & 34.9 & 34.3 \\
\hline \multirow{2}{*}{ Moisture (\%) } & Before & 60.6 & 61.4 & 60.7 \\
\hline & After & 58.7 & 59.8 & 58.1 \\
\hline \multirow{2}{*}{$\mathrm{NH}_{4}-\mathrm{N}\left(\mathrm{mg} \mathrm{kg}^{-1}\right)$} & Before & 2,908 & 2,978 & 2,783 \\
\hline & After & 1,149 & 1,133 & 1,648 \\
\hline \multirow{2}{*}{ TN (\%) } & Before & 1.15 & 1.20 & 1.51 \\
\hline & After & 1.02 & 1.15 & 1.30 \\
\hline \multirow{2}{*}{$\mathrm{C} / \mathrm{N}$ ratio } & Before & 30.6 & 28.5 & 22.2 \\
\hline & After & 35.5 & 30.4 & 26.4 \\
\hline \multirow{2}{*}{$\mathrm{OP}\left(\mathrm{mg} \mathrm{kg}^{-1}\right)$} & Before & 4,924 & 3,096 & 3,106 \\
\hline & After & 4,703 & 1,778 & 1,956 \\
\hline \multirow{2}{*}{$\mathrm{TP}\left(\mathrm{mg} \mathrm{kg}^{-1}\right)$} & Before & 5,716 & 5,611 & 9,075 \\
\hline & After & 8,277 & 8,399 & 10,199 \\
\hline & Before & 86.2 & 55.2 & 34.2 \\
\hline UP/IP (\%) & After & 56.8 & 21.2 & 19.2 \\
\hline $\mathrm{nH}$ & Before & 7.9 & 7.8 & 7.8 \\
\hline рП & After & 9.1 & 8.9 & 9.0 \\
\hline Third batch test & & & & \\
\hline Parameters & Time & Control & $\mathrm{T}^{\mathrm{a}}$ & $\mathrm{T}_{\mathrm{R} 2}{ }^{\mathrm{C}}$ \\
\hline OM (\%) & Before & 31.8 & 31.9 & 29.8 \\
\hline UIVI (\%) & After & 30.4 & 28.0 & 26.1 \\
\hline Moicture (0/) & Before & 63.7 & 63.9 & 64.2 \\
\hline IVIotsture (\%) & After & 63.9 & 66.5 & 67.1 \\
\hline $\mathrm{NH}$ & Before & 2,180 & 2,630 & 2,540 \\
\hline $\mathrm{NH}_{4}-\mathrm{N}$ (mg kg ) & After & 938 & 1,227 & 1,317 \\
\hline & Before & 1.25 & 1.22 & 1.35 \\
\hline $\operatorname{lN}(\%)$ & After & 0.97 & 0.92 & 1.27 \\
\hline $\mathrm{C} / \mathrm{N}$ ratio & Before & 25.5 & 26.3 & 22.1 \\
\hline C/N ratio & After & 31.3 & 30.5 & 20.5 \\
\hline D (mqla $\left.{ }^{-1}\right)$ & Before & 5,350 & 3,940 & 4,850 \\
\hline UP (Ing kg ) & After & 4,810 & 2,870 & 2,310 \\
\hline $\mathrm{TP}\left(\mathrm{mg} \mathrm{kg}^{-1}\right)$ & Before & 6,723 & 6,374 & 9,334 \\
\hline IP (mg kg ) & After & 8,717 & 8,850 & 10,316 \\
\hline & Before & 79.6 & 61.8 & 52.0 \\
\hline UP/IP (\%) & After & 55.2 & 32.4 & 22.4 \\
\hline & Before & 7.8 & 7.3 & 7.3 \\
\hline $\mathrm{pH}$ & After & 8.8 & 8.4 & 8.7 \\
\hline
\end{tabular}

a added 1.2 molar ratio $\mathrm{Mg}$ to $\mathrm{PO}_{4}$ content,${ }^{\mathrm{b}}$ added 1.2 molar ratio $\mathrm{Mg}$ to $\mathrm{PO}_{4}$ content and used the final compost of $\mathrm{T}$ as bulking materials

${ }^{c}$ added 1.2 molar ratio $\mathrm{Mg}$ to $\mathrm{PO}_{4}$ content and used the final compost of $\mathrm{T}_{\mathrm{R} 1}$ as bulking materials 
formation can be found in the OP/TP ratios (Table 2). When Mg supplement was added $\left(T, T_{R 1}\right.$, and $T_{R 2}$ in batch tests $I$, II, and III), the OP/TP ratios before composting decreased, exhibiting smaller ratios than for the control tests. This decrease might be due to MAP crystal formation, because the crystallization process could start immediately after mixing the $\mathrm{Mg}$ with the composting materials. Booker et al. [1999] stated that the MAP formation reaction occurred within $1 \mathrm{~min}$ when the required ions were present in equal molar concentrations. Lee et al. [2009] also reported rapid struvite formation upon addition of Mg supplement, and they observed a decrease in the OP/TP ratio before composting.

After composting, the OP/TP ratio for the controls in batch tests I, II, and III was 47, 57, and 55\%, respectively. When Mg was added, as in $\mathrm{T}$ in batch tests I, II, and III, the OP/TP ratio decreased to 43,21 , and $32 \%$, respectively, and the ratio further decreased to 19 and $22 \%$ when the final compost was recycled in $\mathrm{T}_{\mathrm{R} 1}$ and $\mathrm{T}_{\mathrm{R} 2}$ (batch tests II and III, respectively) as bulking material (in addition to adding the Mg supplement). This decrease in the OP/TP ratio and the gradual increase in the TP content of the final compost should ensure active MAP crystal formation during composting. Furthermore, the decrease in the OP/TP ratio and the increase in the TN and TP contents of the final compost suggest that the compost is converted into a high-nutrient, slow-release fertilizer. Based on these results, it is confident that replacing bulking materials with the MAP-containing compost, as well as using the $\mathrm{Mg}$ supplement, is an effective strategy for enhancing compost quality in terms of nutrients content and composition.

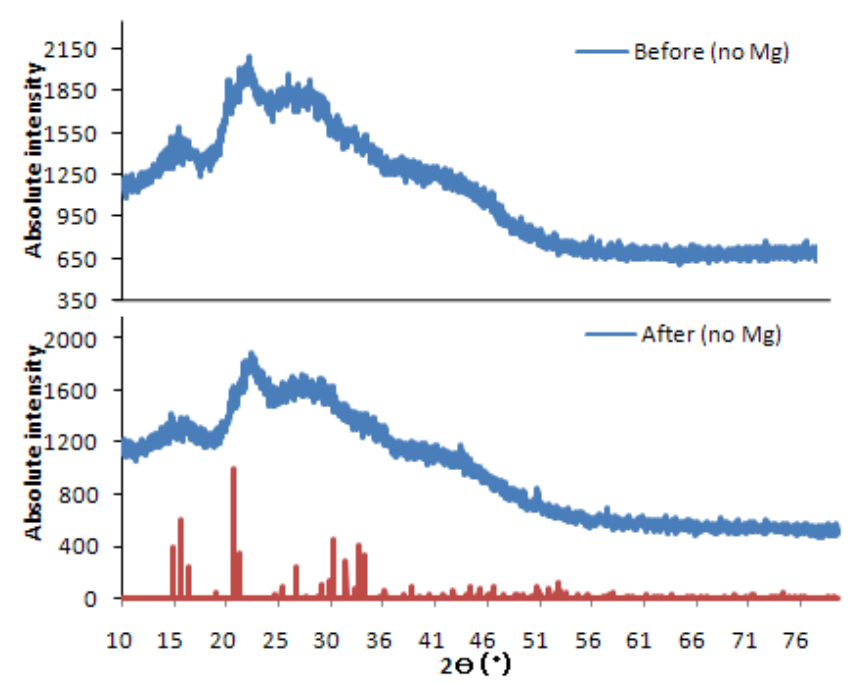

The physical characteristics of the final compost of $\mathrm{T}$ in batch test III was observed using a high magnification visible microscope, and X-ray diffraction (XRD) analyses was carried out to determine the structural property of the crystals formed in the compost. The microscopic observation revealed that orthorhombic, rod-like, or irregular-shaped

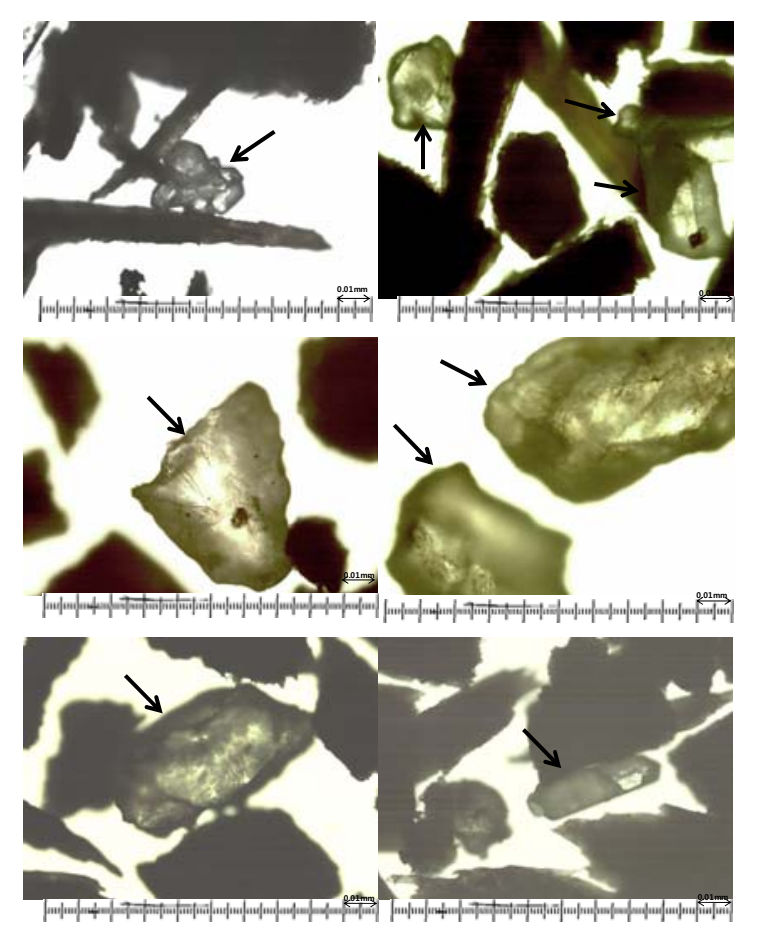

Fig. 2. Various shapes of MAP crystals observed in compost.

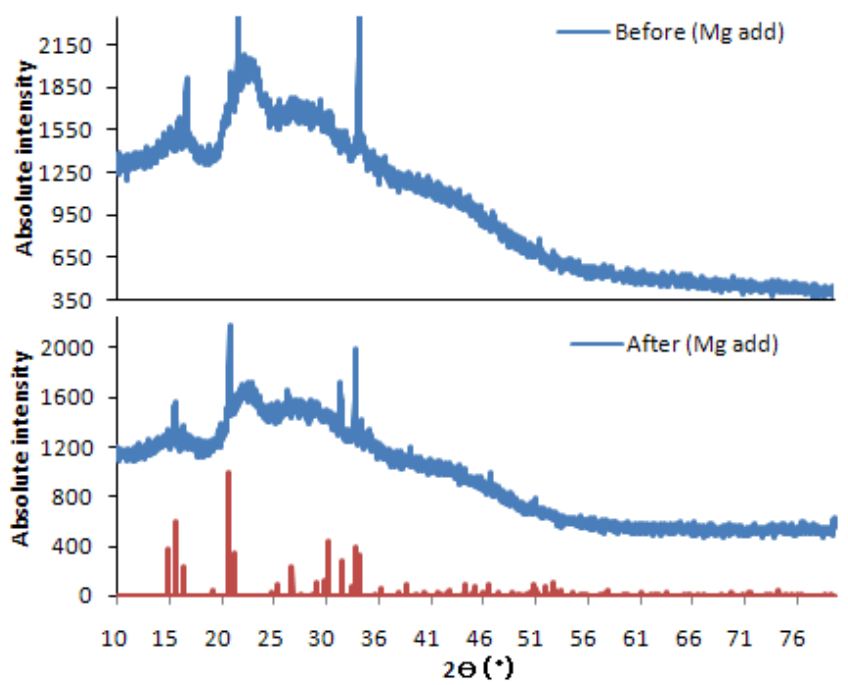

Fig. 3. X-ray diffractogram of compost. 
struvite crystals were formed in the compost (Fig. 2). These crystals are poorly soluble in water and can be used as a slow-release fertilizer [Chirmuley, 1994]. Hao et al. [2008] stated that the size and shape of the struvite crystals are influenced by $\mathrm{pH}$ and that bigger crystals are produced in the $\mathrm{pH}$ range of 7.5 to 8.0 .

Because XRD is considered as the only qualitative method to appropriately judge the structural property of struvite [Doyle et al., 2003], the crystal properties was analyzed by comparing the positions and intensities of the XRD peaks with standard reference values (Fig. 3). For the control cases (no Mg addition), no specific peak was found. However, specific peaks corresponding to the MAP appeared in several positions when the Mg supplement was added, suggesting that the crystals created in the compost are indeed MAP. When a Mg source is added, specific peaks in the compost before and after composting were observed, which indicates that the MAP crystallization reaction begins immediately after adding the $\mathrm{Mg}$ supplement and that it continues during composting.

The physical characteristics of the recycled compost $\left(T_{R 1}\right.$ and $\mathrm{T}_{\mathrm{R} 2}$ ) are also satisfactory in comparison with the controls and the tests where only $\mathrm{Mg}$ is added. The replacement of $50 \%$ of the sawdust with the final MAP-containing compost increases the quality of the compost, as well as its degradability, while reducing composting costs.

\section{CONCLUSIONS}

The effects of adding $\mathrm{Mg}$ and compost recycling on the traits of the final compost were examined. Adding $\mathrm{Mg}$ at a molar ratio of 1.2 with respect to $\mathrm{PO}_{4}$ in swine manure and reusing compost containing MAP crystals did not inhibit organic material degradation during the composting process and converted the compost into a high-nutrient slow-release fertilizer. In particular, the reutilization of compost as bulking material enriched the nitrogen and phosphorus contents in the final compost. The final composts exhibited several specific XRD peaks that correspond to MAP, and irregular-shaped MAP crystals were observed using a visible-light microscope. Upon Mg supplementation, an active MAP crystallization reaction occurred during the composting process, resulting in a decrease in the OP/TP ratio in the composts.

\section{ACKNOWLEDGEMENTS}

This research was performed with the support of "Cooperative Research Program for Agricultural Science and Technology Development (Project No.20070301-036-025-00101-00)", RDA, Korea. Also, this work was supported in part by a grant from the institute of Animal Resources at Kangwon National University.

\section{REFERENCES}

APHA. 1995. Standard Methods for the Examination of Water and Wastewater. $10^{\text {th }}$ Ed., American Public Health Association, Washington, DC.

Booker, N. A., Priestley, A. J. and Fraser, I. H. 1999. Struvite formation in wastewater treatment plants: Opportunities for nutrient recovery. Environ. Technol. 20:777-782.

Bridger, G. L., Salutsky, M. L. and Starostka, R. W. 1962. Metal ammonium phosphates as fertilizers. J. Agr. Food Chem. 10:181-188.

Bueno, P., Tapias, R., Lopez, F. and Diaz, M. J. 2008. Optimizing composting parameters for nitrogen conservation in composting. Bioresource Technol. 99:5069-5077.

Chirmuley, D. G. 1994. Struvite precipitation in WWTPs: Causes and solutions. Water (J. Austr. Water Assoc.) (December): 21-23.

Doyle, J., Oldring, K., Churchley, J., Price, C. and Parsons, S. 2003. Chemical control of struvite precipitation. J. Environ. Eng. 129:419-426.

Graves, R. E., Hattemer, G. M. and Stettler, D. 2000. Composting, Chapter 2. In: National Engineering Handbook, Part-637. United States Department of Agriculture, 210-VI-NEH. Washington, DC, USA.

Hao, X. D., Wang, C. C., Lan, L. and Loosdrecht, M. C. M. V. 2008. Struvite formation, analytical methods and effects of $\mathrm{pH}$ and $\mathrm{Ca}^{2+}$. Water Sci. Technol. 58:1687-1692.

Hoitink, H. A. J. and Fahy, P. C. 1986. Basis for the control of soilborne plant pathogens with composts. Ann. Rev. Phytopathol. 24:93-114.

Jeong, Y. K. and Hwang, S. J. 2004. Optimum doses of Mg and $\mathrm{P}$ salts for precipitating ammonia into struvite crystals in aerobic composting. Bioresource Technol. 96:1-6.

Jeong, Y. K. and Kim, J. S. 2001. A new method for conservation of nitrogen in aerobic composting process. Bioresource Technol. 79:129-133.

Kirchmann, H. and Witter, E. 1989. Ammonia volatilization during aerobic and anaerobic manure decomposition. Plant Soil 115: $35-41$. 
Kithome, M., Paul, J. W. and Bomke, A. A. 1999. Reducing nitrogen losses during simulated composting of poultry manure using adsorbents or chemical amendments. J. Environ. Qual. 28:194-201.

Kuroda, K., Hanajima, D., Fukumoto, Y., Suzuki, K., Kawamoto, S., Shima, J. and Haga, K. 2004. Isolation of thermophilic ammonium tolerant bacterium and its application to reduce ammonia emission during composting of animal wastes. Biosci. Biotechnol. Biochem. 68:286-292.

Lee, J. E., Rahman, M. M. and Ra, C. S. 2009. Dose effects of $\mathrm{Mg}$ and $\mathrm{PO}_{4}$ sources on the composting of swine manure. J. Hazard. Mater. 169:801-807.

Munch, E. V. and Barr, K. 2001. Controlled struvite crystallisation for removing phosphorus from anaerobic digester sidestreams.
Water Res. 35:151-159.

Raut, M. P., William, S. P. M. P., Bhattacharyya, J. K., Chakrabarti, T. and Devotta, S. 2008. Microbial dynamics and enzyme activities during rapid composting of municipal solid waste-A compost maturity analysis perspective. Bioresource Technol. 99:6512-6519.

Stentiford, E. I. 1996. Composting control: Principles and practice. In: de Bertoldi, M., Sequi, P., Lemmes, B., Papi, T. (Eds.), The Science of Composting, Part 1. Blackie, Glasgow, pp. 29-59.

Zhu, N. 2007. Effect of low initial $\mathrm{C} / \mathrm{N}$ ratio on aerobic composting of swine manure with rice straw. Bioresource Technol. 98:9-13.

(Received Nov. 11, 2010; Revised Dec. 15, 2010; Accepted Dec. 17, 2010) 